\title{
Software for interpolation of vegetative growth of yerba mate plants in 3D
}

\author{
Murilo Hilário Mazza da Silva( ${ }^{(1)}$ and Miroslava Rakocevic ${ }^{(2)}$ \\ (1)Embrapa Informática Agropecuária, Caixa Postal 6041, CEP 13083-886 Campinas, SP, Brazil. E-mail: mumazza@gmail.com (2)Instituto \\ Agronômico do Paraná, Caixa Postal 481, CEP 86047-902 Londrina, PR, Brazil. E-mail: miroslava@iapar.br
}

\begin{abstract}
The objective of this work was to build mock-ups of complete yerba mate plants in several stages of development, using the InterpolMate software, and to compute photosynthesis on the interpolated structure. The mock-ups of yerba-mate were first built in the VPlants software for three growth stages. Male and female plants grown in two contrasting environments (monoculture and forest understory) were considered. To model the dynamic 3D architecture of yerba-mate plants during the biennial growth interval between two subsequent prunings, data sets of branch development collected in 38 dates were used. The estimated values obtained from the mock-ups, including leaf photosynthesis and sexual dimorphism, are very close to those observed in the field. However, this similarity was limited to reconstructions that included growth units from original data sets. The modeling of growth dynamics enables the estimation of photosynthesis for the entire yerba mate plant, which is not easily measurable in the field. The InterpolMate software is efficient for building yerba mate mock-ups.
\end{abstract}

Index terms: Ilex paraguariensis, AMAPmod, modeling, plant architecture, plant growth, 3D reconstruction.

\section{Programa computacional para interpolação de crescimento vegetativo de plantas da erva-mate em 3D}

\begin{abstract}
Resumo - O objetivo deste trabalho foi construir maquetes de plantas de erva-mate em vários estágios de desenvolvimento com o uso do programa InterpolMate, e de computar a fotossíntese a partir de estrutura interpolada. Maquetes de erva-mate foram construídas com o software VPlants para três estágios de crescimento. Foram consideradas plantas do sexo masculino e feminino, cultivadas em dois ambientes distintos: monocultura e sub-bosque. Para modelar a arquitetura dinâmica 3D, de plantas individuais de erva-mate, durante o período bienal de crescimento entre duas podas, foram utilizadas informações coletadas em 38 datas do desenvolvimento dos galhos. Os valores estimados a partir das maquetes, incluindo dimorfismo sexual e fotossíntese foliar, são muito próximos aos observados em campo. Contudo, essa semelhança foi limitada às reconstruções que incluíram unidades de crescimento de conjuntos de dados originais. A modelagem da dinâmica de crescimento possibilita estimativas de fotossíntese de plantas inteiras da erva-mate, o que é dificilmente mensurável no campo. O software InterpolMate é eficiente na construção de maquetes de erva-mate.
\end{abstract}

Termos para indexação: Ilex paraguariensis, AMAPmod, modelagem, arquitetura de plantas, crescimento de plantas, reconstrução 3D.

\section{Introduction}

The study of plant architecture emerged as a new scientific discipline some 30 years ago, and was derived from earlier works developed on plant morphology (Hallé et al., 1978). This discipline started with pioneer works on tropical species, modeling at first growth and mortality of meristems in Coffea canephora (Reffye, 1981). The plant architecture corresponds to the natural relative arrangement of each vegetative component, which depends, at any moment, on the balanced expression between endogenous growth processes and exogenous constraints exerted by the environment (Barthélémy \& Caraglio, 2007). The introduction of architectural studies to forestry, horticulture and agronomy has led to a better understanding of plant or population development (Bornhofen \& Lattaud, 2009), and to improvements on the management of forest, orchards and crops (Dauzat et al., 2001; Cici et al., 2008; Costes et al., 2008). 
Plant growth constantly modifies both the structural network of vegetative constituents and the space they occupy. Construction of tree architectural databases over years is time consuming and cannot easily capture event dynamics. The mechanistic models are used to simulate plant function specified at various levels of abstraction of diverse plant species. For example, mechanistic approach has been applied to analyze the relationship between plant structure and environment in cotton (Hanan \& Hearn, 2003), sunflower (Rey et al., 2008), apple (Costes et al., 2008) and some forest (Le Roux et al., 2001) and pasture species (Sonohat et al., 2002). On the other hand, the simulation of plant topology can be modeled using stochastic processes (Costes et al., 2008).

Yerba mate (Ilex paraguariensis St. Hil., Aquifoliaceae) is a subtropical, evergreen tree species, native to South America. Its natural habitat is the subcanopy of the subtropical rainforest with Araucaria angustifolia. The leaves and thin branches of yerba mate are economically important, and represent the primary material for harvesting. After their industrial processing, they are used to prepare a beverage called "chimarrão" in Brazil, and "mate" in the Spanishspeaking countries.

The growth of yerba mate tree is monopodial and rhythmic (Hallé et al., 1978), comprising two annual growth flushes, one in the spring and another in the autumn (Rakocevic et al., 2006a). The lateral branches are grouped before scares of extremely short internodes, which separate annual shoots into successive growth units. As a consequence, the yerba mate form, growth and branch longevity correspond to Rauh's plant architectural model (Hallé et al., 1978). Rakocevic et al. (2006a, 2006b) showed that the growth of adult yerba mate is strongly responsive to open areas and high light conditions, with more intensive leaf emission and leaf area formation in monoculture than in forest shade. Yerba mate also shows structural (Rakocevic et al., 2006b) and physiological (Rakocevic et al., 2009) differences in relation to sexual dimorphism.

All previous structural and physiological studies on yerba mate were carried out at the leaf or branch levels, lacking analyses concerning the plant architecture as a whole.

The objetctive of this work was to build mock-ups of complete yerba mate plants in several stages of development, using the InterpolMate software, and to compute photosynthesis on the interpolated structures.

\section{Materials and Methods}

Three completely known data sets were used to build yerba mate plant mock-ups differencing their sex and cultivation type (monoculture, MO; forest understory, FUS). Those data sets considered three growth stages: spring sprout in October 2003, six months after pruning; summer growth pause in January 2004, nine months after pruning; and beginning of the winter growth pause in June 2005, two years after pruning. Geometry and topology were included in the multiscale tree graphs - MTGs (Godin et al., 1999), using VPlants (Pradal et al., 2009), a successor of the AMAPmod software (Godin \& Guédon, 2003). The MTGs for three growth stages were codified in four scales: plant; trunk, old supports and new branches; growth unit (GU); and internodes (Rakocevic et al., 2008). Branch number and position, internode length, leaf width and lenght and plant photographs were available for the three studied growth stages. The geometrical information on the branch elevation and on the inclination and azimuth of each green leaf relative to the bearing branch were extracted from the photographs. The 3D form of yerba mate individual leaves was reconstructed with five polygons. The phyllotaxy of $137.5^{\circ}$ was atributed for leaf and branch spatial distribution.

The product of leaf length and width values was used as an allometric relationship to estimate the leaf area. The slope of this relationship was determined through leaf subsamples taken from each planting system and sex. Geometrical information, either collected in the field or deduced from the photographs, was combined to topological information included in the MTGs for 3D geometric reconstruction.

The AMAPmod (Godin \& Guédon, 2003) was developed by a team from CIRAD (France) for modeling and analyzing plant architecture, and evolved to VPlants, which is hosted in the OpenAlea (2010), and is Linux and Windows compatible. This software interprets the topological structure from MTGs, which grades plant entities in different scales, allowing the detailing (Silva et al., 2008). MTGs can be constituted of field observations, codifying the botanical architecture in textual form. To model the dynamic 3D architecture of individual yerba mate plants, during the two-year interval (720 days of temporal discontinuity), 38 data sets of branch development were used (Rakocevic et al., 2006a; 2006b). The development was registered every two or four weeks, depending on 
the growth stage (Figure 1). Linear interpolation was applied to compile new data sets based on punctual discrete data sets previously known or derived. In the linear method of interpolation two data points are taken, $\left(\mathrm{x}_{\mathrm{a}}, \mathrm{y}_{\mathrm{a}}\right)$ and $\left(\mathrm{x}_{\mathrm{b}}, \mathrm{y}_{\mathrm{b}}\right)$, and the interpolant at the point $(\mathrm{x}, \mathrm{y})$ is given by:

$$
\mathrm{y}=\mathrm{y}_{\mathrm{a}}+\left[\left(\mathrm{x}-\mathrm{x}_{\mathrm{a}}\right)\left(\mathrm{y}_{\mathrm{b}}-\mathrm{y}_{\mathrm{a}}\right)\right] /\left(\mathrm{x}_{\mathrm{b}}-\mathrm{x}_{\mathrm{a}}\right) .
$$

In order to generate intermediate stages, the InterpolMate uses two mock-ups $\left(\mathrm{x}_{\mathrm{a}}, \mathrm{y}_{\mathrm{a}}\right)$ and $\left(\mathrm{x}_{\mathrm{b}}, \mathrm{y}_{\mathrm{b}}\right)$, related to three $3 \mathrm{D}$ reconstructions, and charts defining biennial yerba mate growth (Rakocevic et al., 2006a, 2006b). The software geometrical parameterization uses four types of morphological characters: main branch elongation; leaf number increase per branch; leaf area increase per branch; and leaf fall per branch. Considering the existence of rhythmicity in yerba mate growth (Hallé et al., 1978; Rakocevic et al., 2006a) and the absence of long term growth linearity, the charts charged with average values served to correct each morphological character during discontinued or "deformed" growth intervals. So, our intention was to elaborate one simple model based on linear interpolation integrated with no-linear corrections of growth. Prior to our model, some authors applied similar strategies,

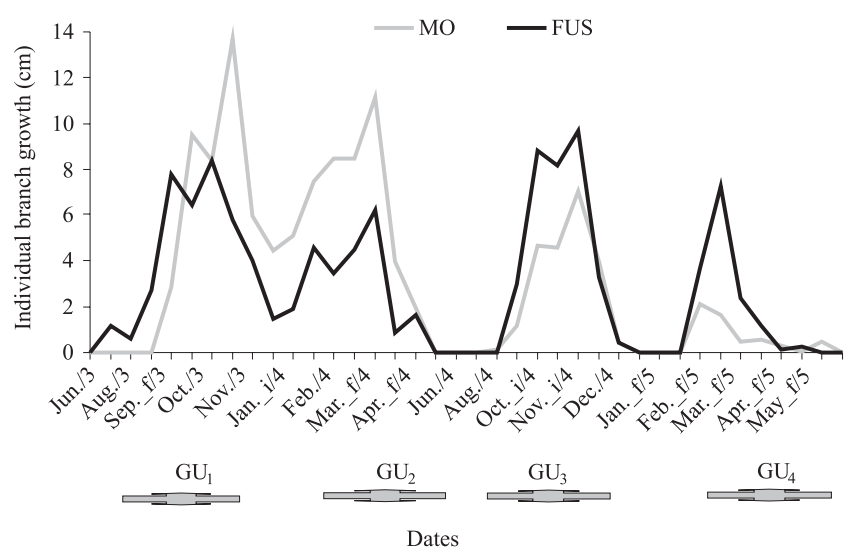

Figure 1. Average growth of yerba mate individual branches, observed between two consecutive measures in two growth environments (MO, monoculture, and FUS, forest understory); $\mathrm{i}$ is initial dates of the month and $\mathrm{f}$ is final dates of the observed month (adapted from Rakocevic et al., 2006a). Four growth unit formations $\left(\mathrm{GU}_{1-4}\right)$ during the two-year period are presented: $\mathrm{GU}_{1}-$ September to December 2003; $\mathrm{GU}_{2}$ - March to May 2004; $\mathrm{GU}_{3}$ - September to December 2004; $\mathrm{GU}_{4}-$ March to May 2005. as Takeshi (2008), who also used linear models to examine the combined effect of seedcone production and climatic factors on Abies mariesii growth.

InterpolMate was developed in Java Standard Edition (Sun Microsystems, 2010) as a stand-alone software, which receives two MTGs as input parameters, representing a plant at two distinct growth stages. From these two MTGs, the interpolation module, implemented on InterpolMate, generates a determined quantity of other MTGs, also defined by the user as an input parameter, and which are relative to the aimed stages of the period between the two stages referring the two MTGs entered by the user. The API technology for Java developed by Khan (2008), named Java Excel API, was used on the development of InterpolMate, aiming at reading and generating .xls files containing MTG information. NetBeans (2010) was used as the integrated development environment (IDE) for the creation of InterpolMate. NetBeans is compatible with Windows and Linux, and its feature tools are of great functionality for the development of the Graphical User Interface (GUI).

To generate each MTG, an automatic algorithm was implemented, which creates a MTG copy referring to its previous growth stage, and, so, the topological structure of this copy is manipulated. Therefore, it is possible to reutilize the alterations occurred in the MTG of the previous growth stage, considering that the model uses the previous morphological events occurred in the previous growth stage of the plant to generate the modifications for the actual MTG. The interpolation can be effected for a minimum one-day difference between two stages. The number of MTGs to be generated, representing each growth stage as output of InterpolMate, is defined by the user.

The first step to be taken with InterpolMate at the graphic interface module is the insertion of the identification of two files containing the MTG of a plant at two distinct dates, representing two different growth stages. After this, the data from each MTG are loaded into the memory data structures. Then, dates concerning growth stages of the MTGs to be generated at the graphical interface are inserted. The user then defines the values of the morphological parameters in the chart editor. InterpolMate is then ready to run the model module to begin the interpolation process that will generate the required MTGs. 
The algorithm implemented in InterpolMate calculates the total branch elongation for a desired plant stage, based on individual branch elongation (Figure 1). This value increases the branch number (considering the MTG of the previous date) and their lengths by the total interpolated value. An algorithm traverses the data structures of branches, feeding each internode in the first MTG from a branch once and, whenever possible, decreasing the fed value for the internode from the total value of branch length acknowledged for that stage, until the total value is null. It searches from bottom to top for an internode to be developed in each main branch, until it finds the internode. If it does not find the internode and the branch data structure traversing is concluded, the same process is executed recursively along the branches of superior orders. When the algorithm finds the internode, the internode length is incremented, and so the same traversing process is executed on the other main branches of the plant, cyclically intercalated. The branch data structure traversing is perfomed when the algorithm recognizes the end of the branch, or an internode in that branch labeled as an internode from the succeeding growth unit. The dominance of main axes was assumed according the Rauh's plant architectural model (Hallé et al., 1978).

The leaf number (Rakocevic et al., 2006b) was treated similarly to branch elongation. An algorithm searches from bottom to top for leaves that must emerge in a main branch. It searches for an internode in a determined branch, which does not have a leaf in the actual MTG, but where it has one in the MTG representing the last stage from the interpolation. If the entire main branch was traversed and no leaf was inserted, the same process is executed in the branches of superior orders. The reconstructed main branches of required stages are of the average length/green leaf number as on charts used for the interpolation model.

For the leaf area (LA) (Rakocevic et al., 2006b), InterpolMate computes the total leaf area that a MTG shall have in a desired stage, considering average values. Firstly, an algorithm calculates the difference between the total LA set for the desired MTG and for the total LA set for the MTG representing the last stage of the interpolation. Dividing the total LA of the desired MTG by this difference, the result is a percentage that shows how much the plant must grow. Secondly, this value is divided by the determined leaf number increment between the desired MTG and the MTG from the last stage. The final result represents the individual leaf area of each new leaf.

As to leaf fall (Rakocevic et al., 2006b), InterpolMate computes the total leaf loss for a MTG in a determined stage. An algorithm searches from bottom to top for leaves that must fall from a branch. The leaf fall policy starts from the main axes, which are defoliated first in the lower layers, initiating by elimination of the oldest ones, placed in the lowest internodes. It searches for an internode in a determined axis, which has a leaf in the desired MTG, but not in the MTG of the last stage of the interpolation. If the entire main branch was traversed and there is no leaf fall, the same process is executed on the branches of superior orders.

All defined morphological parameters show different values for male (MA) and female (FE) plants, and when growth environment (MO and FUS) was analyzed (Rakocevic et al., 2006a, 2006b). This declaration includes the allometric relationship between leaf width and length observed during 38 field observations. The following average allometries of leaf width were plotted for leaf length and used in plant reconstructions: 0.4976 for males and 0.4815 for females in MO; 0.5394 for males and 0.5466 for females in FUS.

The mock-ups were built for eleven distinct dates when real morphological, physiological and microclimatic measures were taken in the field. The frequency of field measures was approximately at each two months during a biennial period between two prunings, from September 2003 to May 2005. Net photosynthesis (A, $\mu \mathrm{mol} \mathrm{CO} \mathrm{m}^{-2} \mathrm{~s}^{-1}$ ) was measured through a LI-6200 analyzer (LICOR, Nebraska, USA), when diurnal assimilation was highest (Rakocevic et al., 2009). The estimated leaf photosynthesis was computed using the VegeSTAR software (Adam et al., 2006) from images of the $3 \mathrm{D}$ mock-ups exported from PlantGLViewer - module of visualization in VPlants (Pradal et al., 2009). Leaf age dependant photosynthesis (Rakocevic et al., 2009) was compared to the estimated one, defined by leaf position in the vertical plant profile of the yerba mate tree crown, using the methodology previously used to calculate light interception in vertical profile (Willaume et al., 2004). The R software (Venables \& Smith, 2010) was used to calculate coefficient of correlation, bias and root mean square error (RMSE), aiming at testing the accuracy of leaf photosynthesis estimations compared to field measures. 


\section{Results and Discussion}

Measures of leaf photosynthesis (Rakocevic et al., 2009) were used for the test of accuracy of a final 3D yerba mate reconstruction. The VegeSTAR outputs for average leaf photosynthesis by layer were plotted against real leaf photosynthesis measurements (Figure 2). Two cases were separated and analyzed, depending on the presence of growth units in the three initial stages and in $3 \mathrm{D}$ reconstructions from Interpol Mate.

Bias demonstrated low negative value (Figure $2 \mathrm{~A}$ ), indicating slow overrestimation of leaf photosynthesis from mock-ups, especially for low photosynthesis values of shaded plants and leaves. The plotted values were near to $1: 1$ line, constructed to validate the modeling accuracy, as shown in Massonnet et al. (2007). RMSE was relatively low, 0.865 for leaf photosynthesis with a $0-15 \mu \mathrm{mol} \mathrm{CO} \mathrm{m}^{-2} \mathrm{~s}^{-1}$ range. The linear regression showed high coefficient of determination $\left(\mathrm{R}^{2}=0.99\right)$ between estimated and measured values.

Nevertheless, the estimations did not adjust satisfactorily when mock-ups were modeled in InterpolMate for $\mathrm{GU}_{2}$ and $\mathrm{GU}_{3}$ (Figure 2 B) with a bias of 1.568, RMSE very far from the idealized 0 , and high coefficient of determination, $\mathrm{R}^{2}=0.87$, between simulated and measured values, showing the

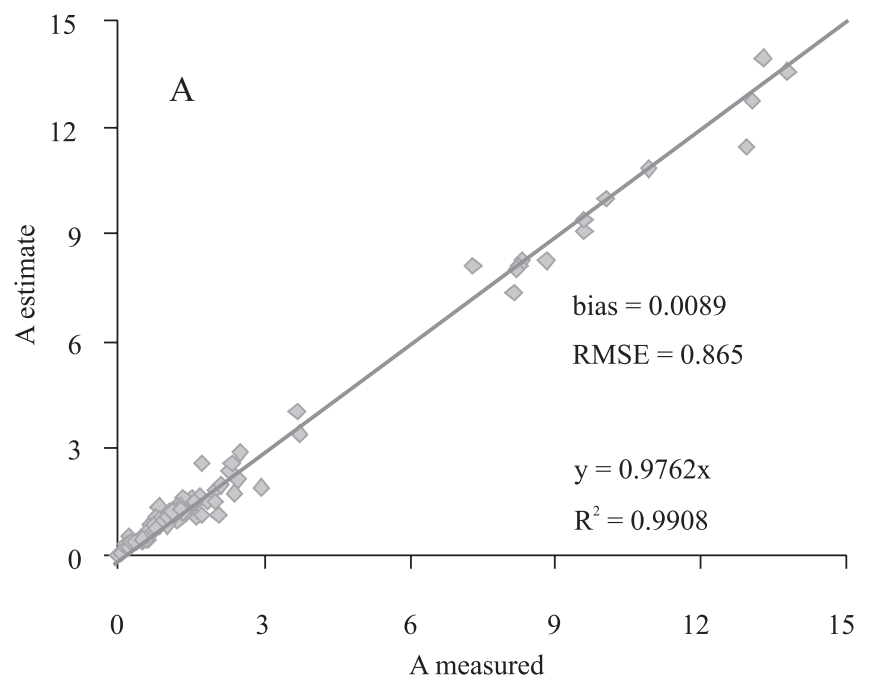

overestimation in interpolated structures. The overestimation was expressed especially for high A values $\left(>10 \mu \mathrm{mol} \mathrm{CO} \mathrm{CO}^{-2} \mathrm{~s}^{-1}\right)$. This is due to the very distinct original data sets used to interpolate (from $\mathrm{GU}_{1}$ to $\mathrm{GU}_{4}$ ), and to the insensibility of the software to recognize the growth rhythmicity and metamer emission/cessation. The interpolation is shown to be quickly implemented, but it does not easily permit fitting the relationships between geometric and topologic branch variables in the structural model construction (Mutke et al., 2005).

The mock-ups of four average plants representing males and females in two contrasting environments are shown in Figure 3, which displays respective plant leaf area, average leafphotosynthesis and total photosynthesis per plant. The 3D reconstructions illustrate six stages considered in Figure 2 A. Leaf photosynthesis was found to be higher in female than in male plants, for various leaf ages in monoculture (Figures $3 \mathrm{C}$, D), while in analyses obtained by Rakocevic et al. (2009), this was shown for stages previous to reproduction, during spring sprout and winter growth pause, only in young fully expanded leaves. The opposite situation in physiological sexual dimorphism was shown in the forest understory, where A values of males were higher that female ones (Figures 3 A, B), while Rakocevic et al. (2009) did not find sexual dimorphism for leaf

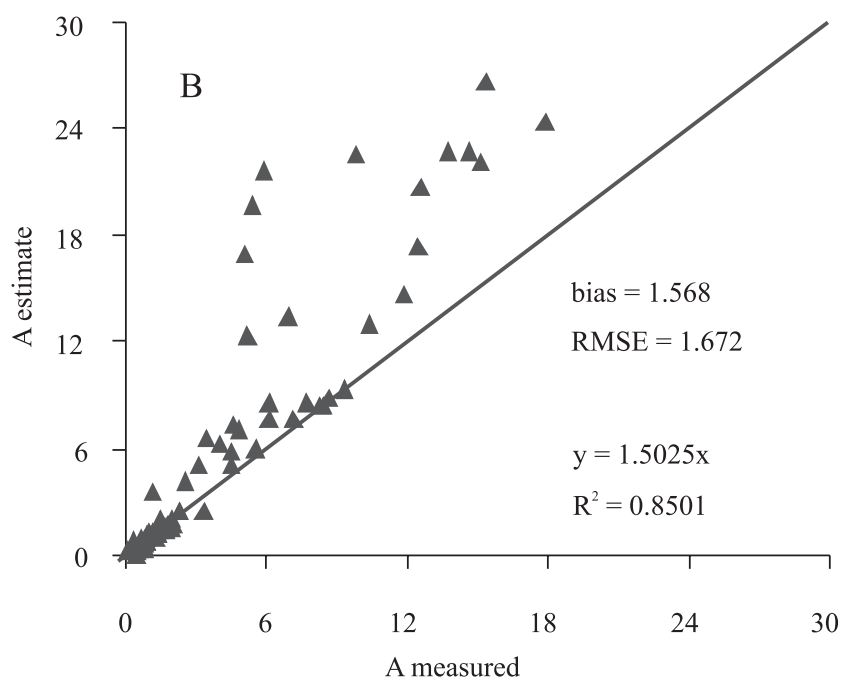

Figure 2. Net leaf photosynthesis $\left(\mathrm{A}, \mu \mathrm{mol} \mathrm{CO} \mathrm{m}^{-2} \mathrm{~s}^{-1}\right)$ measured under field conditions on in different positions of males and females grown in monoculture and forest understory, and estimated in VegeSTAR from mock-ups imported from VPlants. The coefficients of determination for linear regression, bias and RMSE were analyzed for 11 growth stages, from September 2003 to January 2004 and from January 2005 to May 2005 (A); and from March 2004 to November 2004 (B). The 1:1 line is indicated. 
A)
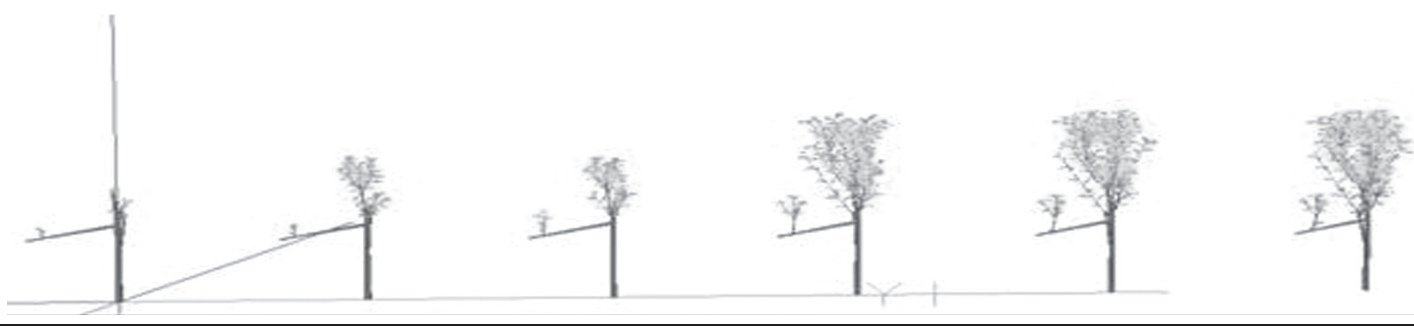

\begin{tabular}{|c|c|c|c|c|c|c|}
\hline Parameter & Sep 2003 & Nov 2004 & Jan 2004 & Jan 2005 & Mar 2005 & May 2005 \\
\hline & \multicolumn{6}{|c|}{ Female under forest understory } \\
\hline Leaf A & 2.800 & 0.915 & 0.700 & 0.743 & 0.529 & 0.912 \\
\hline Leaf area $\left(\mathrm{m}^{2}\right)$ & 0.039 & 0.463 & 0.582 & 2.143 & 2.643 & 2.878 \\
\hline Plant A & 0.108 & 0.424 & 0.408 & 1.592 & 1.398 & 2.625 \\
\hline \multicolumn{7}{|l|}{ B) } \\
\hline \multicolumn{7}{|c|}{ Male under forest understory } \\
\hline Leaf A & 2.451 & 1.597 & 1.452 & 0.807 & 0.778 & 1.183 \\
\hline Leaf area $\left(\mathrm{m}^{2}\right)$ & 0.006 & 0.144 & 0.139 & 1.169 & 1.545 & 1.971 \\
\hline Plant A & 0.015 & 0.230 & 0.202 & 0.943 & 1.202 & 2.332 \\
\hline
\end{tabular}

C)
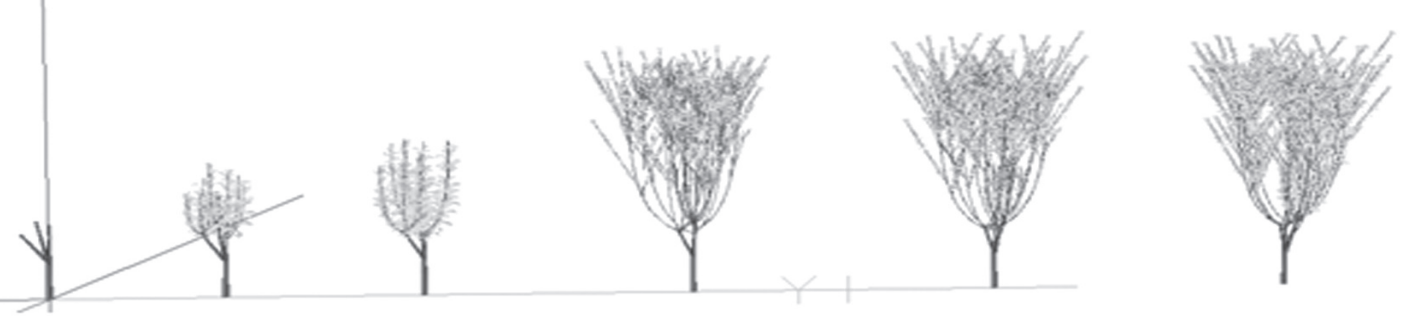

\begin{tabular}{|c|c|c|c|c|c|}
\hline \multicolumn{6}{|c|}{ Female under monoculture } \\
\hline Leaf A & 11.322 & 6.852 & 4.619 & 7.252 & 2.033 \\
\hline Leaf area $\left(\mathrm{m}^{2}\right)$ & 1.182 & 2.004 & 4.692 & 6.780 & 8.941 \\
\hline Plant A & 13.383 & 13.731 & 21.672 & 49.169 & 18.177 \\
\hline \multicolumn{6}{|l|}{ D) } \\
\hline \multicolumn{6}{|c|}{ Male under monoculture } \\
\hline Leaf A & 11.322 & 6.852 & 4.619 & 7.252 & 2.033 \\
\hline Leaf area $\left(\mathrm{m}^{2}\right)$ & 1.182 & 2.004 & 4.692 & 6.780 & 8.941 \\
\hline Plant A & 13.383 & 13.731 & 21.672 & 49.169 & 18.177 \\
\hline
\end{tabular}

Figure 3. Yerba mate mock-ups reconstructed in VPlants and visualized in PlantGLViewer for six distinct stages for females and males grown in forest understory and in monoculture. The regrowth in monoculture $(\mathrm{C}, \mathrm{D})$ were retarded and the crown formation started only at September 2003. Leaf photosynthesis (Leaf A, $\mu \mathrm{mol} \mathrm{CO} \mathrm{m}^{-2} \mathrm{~s}^{-1}$ ); leaf area per plant $\left(\mathrm{m}^{2}\right)$ and plant photosynthesis (Plant A, $\mu \mathrm{mol} \mathrm{CO}_{2} \mathrm{~s}^{-1}$ ) were estimated in VegeSTAR using relative mock-up foliage. 
photosynthesis in yerba mate cultivated under a forest shade. These differences are mostly related to the observation scale. These authors measured A values in field research on individual leaves of various ages, while in the present work, an average leaf A of a plant was computed, counting the presence, surface and quantity of leaves of all ages. The growth dynamics made it possible to estimate the whole plant photosynthesis, not easily obtainable through field measurements. Male plants in FUS assimilated less $\mathrm{CO}_{2}$ than the females, while more robust males in $\mathrm{MO}$ assimilated more $\mathrm{CO}_{2}$ than females.

To adequately follow the structural modifications, some growth models are based on the discrete dynamical systems theory (Giavitto et al., 2002) where mathematical formalism helps to explain rhythm generation and to control the behavior of the system (Mathieu et al., 2008). The InterpolMate software can evolve in the future, by applying mathematically more complex formalism to better fit the relationships between geometry and topology of yerba mate, especially when the searched stage that does not belong to growth units described in known stages is reconstructed. The presented model can also be very useful in reconstructions of species that do not express the growth rhythmicity, as are many tropical species with continuous growth, where the growth variations are only controlled by modifications in the environment.

\section{Conclusions}

1. Simulated plant behaviors, including photosynthesis and sexual dimorphism, are very close to those observed in real plants, but only in reconstructions that consider the growth units from original data sets.

2. The validations are very satisfactory for stages reconstructed during plant development, for the time interval that considers most recently emitted growth units.

3. The linear interpolation method used for reconstruction of diverse stages is quick and easy, but it is not very precise.

\section{Acknowledgements}

To Eduardo Delgado Assad, Adriano Franzoni and Sílvio Evangelista, colleagues from Embrapa
Informática Agropecuária, for the support: to Paulo Henrique Caramori, from Instituto Agronômico do Paraná, for the manuscript overview, and to Ms. Célia Goodwin, for the English text revision; to InterAmerican Institute for Cooperation on Agriculture and Araucaria Foundation, Paraná State, Brazil, for the grants conceded to Miroslava Rakocevic .

\section{References}

ADAM, B.; DONES, N.; SINOQUET, H. VegeSTAR: software qui calcule l'interception lumineuse et la photosynthèse. Version 3.2. Clermont-Ferrand: INRA, 2006. Available at: <http://www2. clermont.inra.fr/piaf/eng/download/download.php $>$. Accessed on: 22 Apr. 2010.

BARTHÉLÉMY, D.; CARAGLIO, Y. Plant architecture: a dynamic, multilevel and comprehensive approach to plant form, structure and ontogeny. Annals of Botany, v.99, p.375-407, 2007.

BORNHOFEN, S.; LATTAUD, C. Competition and evolution in virtual plant communities: a new modeling approach. Natural Computing, v.8, p.349-385, 2009

CICI, S.Z.H.; ADKINS, S.; HANAN, J. A canopy architectural model to study the competitive ability of chickpea with sowthistle. Annals of Botany, v.101, p.1311-1318, 2008.

COSTES, E.; SMITH, C.; RENTON, M.; GUÉDON, Y.; PRUSINKIEWICZ, P.; GODIN, C. MAppleT: simulation of apple tree development using mixed stochastic and biomechanical models. Functional Plant Biology, v.35, p.936-950, 2008.

DAUZAT, J.; RAPIDEL, B.; BERGER, A. Simulation of leaf transpiration and sap flow in virtual plants: model description and application to a coffee plantation in Costa Rica. Agricultural and Forest Meteorology, v.109, p.143-160, 2001.

GIAVITTO, J.-L.; GODIN, C.; MICHEL, O.; PRUSINKIEWICZ, P. Computational models for integrative and developmental biology. Evry: Universit'e d'Evry Val d'Essonne, 2002. 42p. (Rapport de recherche, 72-2002). Available at: $<$ http://mgs.spatialcomputing.org/PUBLICATIONS/lami-RR72--computationalmodels-for-dynamical-structure.pdf $>$. Accessed on: 22 Apr. 2010.

GODIN, C.; COSTES, E.; SINOQUET, H. A method for describing plant architecture which integrates topology and geometry. Annals of Botany, v.84, p.343-357, 1999.

GODIN, C.; GUÉDON, Y. AMAPmod version 1.8: introduction and reference manual. Montpellier: Cirad, 2003.

HALlÉ, F.; OLDEMAN, R.A.A.; TOMLINSON, P.B. Tropical trees and forests: an architectural analysis. Berlin: SpringerVerlag, 1978. 441p.

HANAN, J.S.; HEARN, A.B. Linking physiological and architectural models of cotton. Agricultural Systems, v.75, p.47-77, 2003.

KHAN, A. Java Excel API: a Java API to read, write, and modify Excel spreadsheets. Available at: $<$ http://jexcelapi.sourceforge. net/>. Accessed on: 8 Nov. 2008. 
LE ROUX, X.; LACOINTE, A.; ESCOBAR-GUTIÉRREZ, A.; LE DIZÈS, S. Carbon-based models of individual tree growth: a critical appraisal. Annals of Forest Science, v.58, p.469-506, 2001 .

MASSONNET, C.; COSTES, E.; RAMBAL, S.; DREYER, E.; REGNARD J.-L. Stomatal regulation of photosynthesis in apple leaves: evidence for different water-use strategies between two cultivars. Annals of Botany, v.100, p.1347-1356, 2007.

MATHIEU,A.; COURNÈDE P.-H.; BARTHÉLÉMY, D.; REFFYE, P. de. Rhythms and alternating patterns in plants as emergent properties of a model of interaction between development and functioning. Annals of Botany, v.101, p.1233-1242, 2008.

MUTKE, S.; SIEVÄNEN, R.; NIKINMAA, E.; PERTTUNEN, J.; GIL, L. Crown architecture of grafted Stone pine (Pinus pinea L.): shoot growth and bud differentiation. Trees - Structure and Function, v.19, p.15-25, 2005.

NETBEANS. NetBeans: platform. Available at: <http://java.sun. com/javase/downloads/netbeans.html $>$. Accessed on: 22 Apr. 2010.

OPENALEA. OpenAlea software environment: platform. Available at: $<$ http://openalea.gforge.inria.fr/dokuwiki/doku.php>. Accessed on: 22 Apr. 2010.

PRADAL, C.; BOUDON, F.; NOUGUIER, C.; CHOPARD, J.; GODIN, C. PlantGL: a python-based geometric library for 3D plant modelling at different scales. Graphical Models, v.71, p.1-21, 2009.

RAKOCEVIC, M.; MEDRADO, M.J.S.; LUCAMBIO, F.; VALDUGA, T.A. Caracterização de crescimento do caule da erva-mate (Ilex paraguariensis St. Hil.) cultivada em dois ambientes luminosos contrastantes. In: CONGRESO SUDAMERICANO DE LA YERBA MATE, 4.; REUNIÓN TÉCNICA DE LA YERBA MATE, 4.; EXPOSICIÓN DE AGRONEGOCIOS DE LA YERBA MATE, 2., 2006, Posadas. Anais. Posadas: INTA, 2006a. p.244-249.

RAKOCEVIC, M.; MEDRADO, M.J.S.; LUCAMBIO, F.; VALDUGA, T.A. Ritmicidade de emissão e de queda de folhas e as suas conseqüências no manejo da erva-mate. In: CONGRESO SUDAMERICANO DE LA YERBA MATE, 4.; REUNIÓN TÉCNICA DE LA YERBA MATE, 4.; EXPOSICIÓN DE AGRONEGOCIOS DE LA YERBA MATE, 2., 2006, Posadas. Anais. Posadas: INTA, 2006b. p.250-256.

RAKOCEVIC, M.; MEDRADO, M.J.S.; MARTIM, S.F.; ASSAD, E.D. Sexual dimorphism and seasonal changes of leaf gas exchange in the dioecious tree Ilex paraguariensis grown in two contrasted cultivation types. Annals of Applied Biology, v.154, p.291-301, 2009.

RAKOCEVIC, M.; SILVA, M.H.M. da; ASSAD, E.D.; MEGETO, G.A.S. Reconstrução de maquetes 3D e manipulação da arquitetura de espécies perenes cultivadas no Brasil. Pesquisa Agropecuária Brasileira, v.43, p.1241-1245, 2008.

REFFYE, P. Modèle mathématique aléatoire et simulation de la croissance et de l'architecture du caféier Robusta. I. Etude du fonctionnement des méristèmes et de la croissance des axes végétatifs. Café, Cacao, Thé, v.25, p.83-104, 1981.

REY, H.; DAUZAT, J.; CHENU, K.; BARCZI, J.-F.; DOSIO, G.A.A.; LECOEUR, J. Using a 3-D virtual sunflower to simulate light capture at organ, plant and plot levels: contribution of organ interception, impact of heliotropism and analysis of genotypic differences. Annals of Botany, v.101, p.1139-1151, 2008.

SILVA, D. da; BOUDON, F.; GODIN, C.; SINOQUET, H. Multiscale framework for modeling and analyzing light interception by trees. Multiscale Modeling and Simulation, v.7, p.910-933, 2008.

SONOHAT, G.; SINOQUET, H.; VARLET-GRANCHER, C.; RAKOCEVIC, M.; JACQUET, A.; SIMON, J.-C.; ADAM, B. Leaf dispersion and light partitioning in three-dimensionally digitized tall fescue-white clover mixtures. Plant, Cell and Environment, v.25, p.529-538, 2002.

SUN MICROSYSTEMS. Using Runtime.exe to invoke child processes and programming with file attributes. Available at: $<$ http://java.sun.com/developer/JDCTechTips/2003/tt0304.html >. Accessed on: 22 Apr. 2010.

TAKESHI, S. Influence of annually fluctuating seed-cone production and climatic factors on the upper-crown expansion of canopy trees of Abies mariesii Masters (Pinaceae). Plant Species Biology, v.23, p.129-139, 2008.

VENABLES, W.N.; SMITH, D.M. An introduction to R.: notes on R: a programming environment for data analysis and graphics. Version 2.11 .0 (2010-04-22). Available at: <http://cran.r-project. org/doc/manuals/R-intro.pdf $>$. Accessed on: 27 Apr. 2010.

WILLAUME, M.; LAURI, P.-É.; SINOQUET, H. Light interception in apple trees influenced by canopy architecture manipulation. Trees: Structure and Function, v.18, p.705-713, 2004.

Received on September 5, 2009 and accepted on February 3, 2010

Pesq. agropec. bras., Brasília, v.45, n.3, p.244-251, mar. 2010 